\title{
Palaeohispanic Languages and Epigraphies
}

\section{Chapter 8}

\section{Cultural and linguistic contacts in southern Gaul}

\author{
Alex Mullen* and Coline Ruiz Darasse
}

\section{Introduction}

Southern Gaul, on the edge of a sea criss-crossed with traffic for thousands of years, will always have entertained multiple voices. ${ }^{1}$ From about the sixth century BC the area enters the historical stage with the foundation of Marseille and we begin to see the region as a meeting point of various actors: speakers of Iberian, Greek, Etruscan, Italic languages, Phoenician, Punic, 'Ligurian', Gaulish and other Celtic languages. Comparanda would suggest that the majority of these speakers were bi- or multi-lingual. The identification of 'ethnic', tribal or other population groups in this context remains difficult and at the mercy of the bias of Classical sources. ${ }^{2}$ Nevertheless we can explore direct and indirect traces of cultural and linguistic contacts in southern Gaul up to the Augustan period through inscriptions written in a range of scripts. ${ }^{3}$ The epigraphic landscape of southern Gaul can be very roughly divided, at least until the time of Augustus, into two broad zones: to the west of the river Hérault the Levantine or north-eastern Iberian semisyllabary, a Palaeohispanic script, dominates; to the East the picture is influenced more by the presence of the Greek script. We should remember, however, that this division between south-western and south-eastern zones is a convenient scholarly one and would not necessarily have been salient for the ancient population groups.

\section{Early contacts with the Mediterranean world: Greek, Etruscan and Phoenicio-Punic}

The first non-indigenous actors to settle widely in southern Gaul were the Phokaian Greeks who peppered the coastline and river valleys with settlements of various sizes and types across both zones from Nikaia (Nice, Alpes-Maritimes) in the south-east to Emporion (Empúries, Catalonia) and beyond (MAP 1). ${ }^{4}$ Unsurprisingly the Greeks left epigraphic remains, though in relatively low numbers, perhaps mirroring the practice at the metropolis, Phokaia (Asia Minor). ${ }^{5}$ The pre-Imperial Greek epigraphic record of southern Gaul, set out in Inscriptions grecques de la France (IGF), which is largely, but not entirely, restricted to lapidary inscriptions, numbers only approximately twenty-five out of a total of 169 , of which most can be linked to Greek settlements, the coast and trading contexts. A recent collection of lapidary inscriptions not available for $I G F$ and of non-lapidary inscriptions not included in IGF's remit (Mullen 2013a Appendix 2) does not change the picture considerably, though a few 'non-Greek' sites appear. ${ }^{6}$ Of the thirty-seven entries in this collection dated to pre-100 BC, nineteen are from known Greek, or partially Greek settlements, and a further six can be associated

\footnotetext{
* Mullen's research receives funding from the European Research Council (ERC) under the European Union's Horizon 2020 research and innovation programme under grant agreement No. 715626.

${ }^{1}$ For the connectedness of the Mediterranean, see Horden and Purcell 2000. For southern Gaul within the Mediterranean context, see Bouffier and Garcia 2017; Garcia 2014; Mullen 2013.

${ }^{2}$ For a detailed synthesis, see Hoz 2010: 66-115 and 2011a: 115-216.

${ }^{3}$ For a survey and bibliography of direct and indirect linguistic contacts in the Iberian peninsula in English, see Simkin 2012.

${ }^{4}$ For details of the foundations, see Morel 2006, 2006 [2009].

${ }^{5}$ See Mullen 2013a: 158-161.

${ }^{6}$ For a discussion of the collection, see Mullen 2013a: 163-169.
} 
with trading contexts. The remaining twelve entries hail from Vaugrenier (Alpes-Maritimes), Le Castellan, Marignane, Martigues (Bouches-du-Rhône), Béziers, Ensérune (Hérault), Elne, Ruscino (Pyrénées-Orientales), Canonges, Mailhac, Montlaurès, Pech Maho (Aude), and offer a slight bias towards the south-western zone. The $I G F$ and non-IGF Greek pre-Roman inscriptions show almost no evidence of linguistic contacts with non-Greek groups in naming practices and the evidence for bilingual texts is virtually non-existent. Although it is difficult to be sure given the low levels of epigraphy in the pre-Roman period and therefore an absence of a key type of evidence, it seems that Phokaian Greek interaction with local populations, including the Iberians, may not have been of a type which facilitates deep linguistic interactions and many colonial Greeks may have focused primarily on their settlements and Mediterranean rather than Continental entanglements.

The earliest direct evidence for linguistic contacts in southern Gaul does, however, come from the Greek world. The Ionic Greek Pech Maho (Aude) tablet (IGF 135), dated to around 425 BC, relays the details of a commercial transaction in which Iberian-named individuals, and perhaps others from local population groups, appear as witnesses in the process. The tablet, written in Greek, is probably to be understood within the economic sphere of the Phokaian colony Emporion and conforms to the norms of Greek contracts. ${ }^{7}$ The document has traditionally been understood as an account of a transaction, ${ }^{8}$ though has recently been reinterpreted as the deposition of a plaintiff in a legal context. ${ }^{9}$ This exceptional text is one of the very few to illustrate the entanglements between Greeks and local populations, including Iberians, in this pre-Roman phase. Another example, this time less clear, can be found in a name inscribed on an Attic skyphos, dated to the fourth century BC and found at Peyriacde-Mer (Aude). The name transcribed through the Greek alphabet, KANIK $\Omega N E,{ }^{10}$ has been interpreted either as an Iberian name ${ }^{11}$ or as a Gaulish one. ${ }^{12}$ Indeed the final -e may suggest an adaptation of a Celtic name to the Iberian language as occurs elsewhere. ${ }^{13}$ The discovery at Lattes (near Montpellier, Hérault) of two alphabets of a later date, from around $200 \mathrm{BC}$, with one followed by the term knax which appears on the educational papyri from Egypt, indicates that instruction in the Greek alphabet, at least, may have been occurring in coastal areas of south-western Gaul. Whether this instruction was ever formalized and took place in 'schools' is impossible to tell, and it is unclear whether the instruction was occurring between Greeks or involved other population groups. At a settlement as multicultural as Lattes, with its evidence for possible Etruscan residents for example, we would need more than this meagre evidence to understand a potentially complex picture.

Indeed the Etruscan presence in southern Gaul is most securely attested at Lattes, ancient Lattara, ${ }^{14}$ a settlement, established around $500 \mathrm{BC}$, which appears to have welcomed a range of population groups. Evidence for the proposed Etruscan presence includes Etruscan inscriptions and cookware and demonstrates that the well-attested Etruscan commerce did not just occur in ad hoc fashion or at arm's

\footnotetext{
${ }^{7}$ Ampolo, Caruso 1990-1991.

${ }^{8}$ Lejeune, Pouilloux, Solier 1988.

${ }^{9}$ Gorgues 2016.

${ }^{10}$ Bats 1988: 125-126.

${ }^{11}$ Marqués de Faria 1999: 155; Lejeune 1993: 83 note 92.

${ }^{12}$ Canicus/os: Bats 2011b: 210.

${ }^{13}$ cf. katubaŕe/Catumaros at Ensérune (Hesperia HER.02.373).

${ }^{14}$ Py 1995; Py 2009; Belfiore 2015.
} 
length. ${ }^{15}$ One fifth-century inscription in South-Etruscan script from Lattes seems to consist of an Etruscan version of a Celtic name in the genitive: Ucial. ${ }^{16}$ Etruscan texts are also recorded at Marseille, Saint-Blaise, possibly Béziers, ${ }^{17}$ and the 'other side' of the Pech Maho tablet contains an Etruscan text which can be dated to $450 \mathrm{BC}$ demonstrating relations between Massaliote Greeks and Etruscans. ${ }^{18}$ Whilst it is impossible to be sure where this text was written, and it seems to bear no direct relationship with the Greek text of the other side, i.e. it is not a bi-version bilingual text, it clearly fits into the cultural contacts of southern Gaul because the place name Marseille is attested in Etruscan form in line 5: Mataliai. The text also mentions an Etruscan individual Venelus (line 1, as Veneluz in 1. 3, possibly from Orvieto/Volsinies) and possibly a Latin-named individual in line 3, Utavu (which may be Octavius).

Another inscription dating to between the fifth and fourth centuries BC from Ensérune illustrates interactions between Etruscans and Celtic-speaking populations, recording a Celtic feminine name written in the genitive in the Etruscan alphabet: Smeraz (originally considered to be in Iberian script: HER.02.002b celta, Fig. 1). ${ }^{19}$ However, a local Celtic epigraphy in Etruscan script is not created as it is around Lake Lugano in northern Italy ${ }^{20}$ and, in parallel with the practice of the Greeks, it is therefore possible to argue that the Etruscans may not have been deeply entangled with local populations. Nevertheless, the epigraphic record does contain apparent examples of interaction between Etruscans and Greek- and Celtic-speaking communities, which is striking given the meagre total volume of inscriptions from this early period. In the current state of documentation, however, we cannot identify clear direct evidence of linguistic contact between Etruscans and Iberians or non-Celtic local populations anywhere in southern Gaul.

Similarly we currently do not have proof of linguistic contacts between Phoenician or Punic speakers and the populations of southern Gaul. ${ }^{21}$ Nonetheless it is unquestionable that economic and commercial interactions had been taking place in the region with Phoenicians from the seventh century $\mathrm{BC}$ onwards since diagnostic products have been found in coastal areas and further inland, focused mainly in the western zone. ${ }^{22}$ These primarily include large vessels such as Ibero-Punic or PhoenicioPunic amphorae and sometimes other items such as coins and the small mask found at Collioure (Pyrénées-Orientales), ${ }^{23}$ though none so far carries any written record. ${ }^{24}$ The pre-Roman epigraphic record is patchy, especially before about the fourth century $\mathrm{BC}$, but we can be sure that

\footnotetext{
${ }^{15}$ Colonna 1980 and Py 1995 discuss Etruscan inscriptions (in South-Etruscan script) from Lattes.

${ }^{16}$ Colonna 2006: 665-666; Hoz 2008: 18; Bats 2011b: 204.

${ }^{17}$ Two fragmentary fifth-century graffiti from Béziers have been reanalysed as being in Etruscan script, see Bats $2011204-205$.

${ }^{18}$ See Briquel et al. 2006; Colonna 2006; Gran-Aymerich 2006 for recueils of Etruscan inscriptions from Gaul.

${ }^{19} \mathrm{Hoz} 2008$.

${ }^{20}$ See RIG II.1. The only evidence of the Lugano alphabet (used to write Lepontic and Cisalpine Gaulish) in Transalpine Gaul is the enigmatic so-called Padane drachma, see Bats 1988a : 131, 141-142; 2000: 75-76, 2003: 374 note 10; Deroc 1983; Häussler 2002: 62-63, 2008: 57-59, and possibly an inscription on Campanian A ware from Baou de Saint-Marcel (Bouches-du-Rhône): ( )oidsa(i), see Bats 1988a: 141-142.

${ }^{21}$ For Phoenician and Punic inscriptions in the West (Malta, Sicily, Sardinia, Spain), see Amadasi Guzzo 1967, none so far originates from southern Gaul.

${ }^{22}$ For Phoenicio-Punic activity, see Dietler 1997: 289-291, 336, 2010 7; Py 1993: 44-45, 88.

${ }^{23}$ The mask (an anthropomorphic terracotta plaque) is currently lost, see CAG 66, 308, fig. 224; Ponsich 1996.

${ }^{24}$ Phoenicio-Punic amphora at Caunes-Minervois (CAG 11.2: 246-247); Phoenician (or Ibero-Punic) amphora at Carsac (CAG 11.2: 225)
} 
Punic/Phoenician-, Etruscan- and Greek-speaking traders from around the Mediterranean, ${ }^{25}$ at times regularly, at others sporadically, interacted, and sometimes settled, alongside the Phokaian Greeks and the 'indigenous' Celtic and other communities.

In terms of the interaction between Greek settlers and 'indigenous' populations, it seems that no indigenous sites show a profound assimilation to a Greek way of life: nowhere is evidence of 'becoming Greek' systematically traceable, something that can be compared to the more penetrating, though still complex, processes of 'becoming Roman' attested increasingly from around the turn of the millennium; ${ }^{26}$ rather, some indigenous groups seem to adopt select aspects of Greek culture for their own purposes. ${ }^{27}$ Without doubt, external influences did have a significant impact on southern Gaul; in particular, the increased trade and contact provoked a response from indigenous communities, namely a movement away from subsistence and consequently increased settlement fixity. ${ }^{28}$ The settlements undergoing most rapid transformation were often those closest to the coast, and presumably, therefore, to the maritime koine, and to Greek centres, ${ }^{29}$ although many indigenous settlements in the direct hinterland of Marseille seem to have experienced tense, sometimes hostile, relationships with the colony and retained distinctively indigenous facies. ${ }^{30}$ Nevertheless the diversity of reactions and the continuation of many traditional aspects demonstrate that the process was far from straightforward assimilation but rather 'l'effet conjugué des stimulations externes et des motivations locales'. ${ }^{31}$ These external stimuli emanated from all around the Mediterranean basin, including the Iberian peninsula, though it is often hard to disentangle, quantify and qualify their precise origins.

\section{Contacts with the Iberian world}

The first contacts between the Iberian world and southern Gaul can be illustrated by the transfer of production practices and techniques. Already occurring in the Bronze Age, these transfers intensified during the sixth century $\mathrm{BC}$ and are particularly obvious in ceramic wares. ${ }^{32}$ This interaction resulted in local products of mixed characteristics. ${ }^{33}$ In terms of transfer of techniques, this can be seen in the production of tableware, the practice of storage in buried silos and, from the fourth century $\mathrm{BC}$, the practice of writing.

In southern Gaul, Palaeohispanic epigraphy appears as ownership marks on imported ceramics and stamps on dolia, on a dozen sheets of lead, coins, and, very rarely, on stone. The epigraphy is largely a feature of the third to first centuries BC and rapidly disappears under the Roman Empire. A few sites produce this epigraphy: two in the Pyrénées-Orientales (Ruscino/Château-Roussillon et Elne), one in

\footnotetext{
${ }^{25}$ For non-Phokaian Greek activity, see Mullen 2013a 31.

${ }^{26}$ For Gauls 'becoming Roman', see Woolf 1998.

${ }^{27}$ The status assigned to wine in southern Gaul has been a focus; southern Gaul shows a distinctive pattern of consumption, see Dietler 1999; Horden and Purcell 2000: 220. Aspects of Greek culture not generally adopted include Greek bodily adornment, garum and olive oil, see Dietler 1999, 2010. Kleiner (1973: 382) also refers to the 'virtual absence of a sculptural tradition that can fairly be termed Greek'. For the distinctive responses of the Iberians to 'Hellenization', see Domínguez 1999.

${ }^{28}$ Py 1993: 107-122.

${ }^{29}$ Py 1993: 93, 149.

${ }^{30}$ See Bernard, Collin-Bouffier, Tréziny 2010.

${ }^{31}$ Py 1993: 83. For other aspects, e.g. burial and social patterns, in this period, see Py 1993: 83-150.

${ }^{32}$ Gailledrat 1997; 2014.

${ }^{33}$ Gailledrat 1993.
} 
Hérault (Ensérune), five in Aude (Mailhac, Montlaurès, Pech Maho, Peyriac-de-Mer, Tourouzelle) and one in Haute-Garonne (Vieille-Toulouse). In Cerdagne ten sites provide 37 inscribed rocks (145 texts and 1475 signs) which appear to respond to specific local issues and constitute a closed group. ${ }^{34}$ Inscriptions have also been found on three sites (Lattes (Hérault), Gruissan (Aude) and Aubagnan (Landes ${ }^{35}$ ) which are on imported inscribed objects and are not evidence for a local practice of using Palaeohispanic scripts. The first one is a lead bar written in meridional script; ${ }^{36}$ its origin and date are unknown. The inscription found at Gruissan is on a large bronze plate and in Celtiberian language, probably part of the shipment of a wreck. ${ }^{37}$ Finally, the inscriptions from Aubagnan are clearly a manufacturer's signature and were most probably inscribed when the phiales were produced (perhaps in Tivissa, given the proximity of the productions found there (see below)). ${ }^{38}$ With the exception of Ensérune which offers a corpus of nearly 400 inscriptions, none of these 'Palaeohispanic' sites provides many inscriptions.

The presence of the north-eastern Iberian script in southern Gaul is one of the supporting arguments for Javier de Hoz's hypothesis that Iberian was a lingua franca. This view sees the origin of Iberian language and culture in the southern part of the Valencian Country, in Contestania, and an expansion from south to north of the language and north-eastern Iberian or Levantine script. ${ }^{39}$ Iberian would have served as a lingua franca, particularly in the trading realm between different population groups in the northern Iberian zone and in south-western Gaul. Although other scripts were in use, these populations chose the north-eastern Iberian semi-syllabary. The Palaeohispanic inscriptions from Ensérune offer an Iberian anthroponymic stock which matches that found in the Iberian peninsula (e.g. selkiteŕ HER.02.024, Fig. 2) but also many Celtic personal names (e.g. katubaŕe HER.02.373) ${ }^{40}$ It seems that there were therefore, from the fourth century $\mathrm{BC}$, close links between the Celtic and Iberian populations at this site, such that local workers even chose the north-eastern script, although not well suited to their language, for their stamps on dolia. Other obscure names appear to belong to a local substrate language uncovered by Jürgen Untermann ${ }^{41}$ and for which Javier de Hoz was able to identify a few traits based on toponyms and hydronyms in Ptolemy's Geography. ${ }^{42}$ These populations, which seem to be neither Celtic- nor Iberian-speaking, were conventionally called 'Ligurian' based on Classical texts such as the periplus of Pseudo-Scylax who describes the cohabitation of 'Ligurian' and Iberian groups between Emporion and the Rhône. This nomenclature has been the source of numerous confusions and conflations. ${ }^{43}$ In fact we now tend to mention 'Ligurians' within inverted commas or avoid its use altogether; Javier de Hoz talks of a 'ligur-languedociense' or 'liguroïdes' stratum. ${ }^{44}$ Essentially a phantom in our attested evidence, this language and its speakers may have been important elements in the linguistic and cultural entanglements of southern Gaul and remind us of our unavoidable bias towards those who can and choose to write.

\footnotetext{
${ }^{34}$ For the corpus and synthesis, see Campmajo 2012. See also Ferrer i Jané 2015.

${ }^{35}$ Gorrochategui 1984: 50.

${ }^{36}$ HER.01.03 (= MLH II, B.2.3 = MLH III, G.18.1).

${ }^{37}$ AUD.04.01 (= MLH II, B.3.1 = MLH IV, K.17.1).

${ }^{38}$ LAN.01.01 and LAN 01.02 (= MLH II, B.10.1 and B.10.2).

${ }^{39}$ For a recent presentation, see $\mathrm{Hoz} 2011 \mathrm{~b}$.

${ }^{40}$ Correa 1993; Ruiz Darasse 2010; Hoz 2011a: 158-162.

${ }^{41}$ Untermann 1969.

${ }^{42}$ Hoz 2005.

${ }^{43}$ For a general overview, see Untermann 2006.

${ }^{44} \mathrm{Hoz} 2005$ : 80.
} 
Our poor knowledge of Iberian does not allow us to understand the rare long texts that we have. ${ }^{45}$ It is not currently possible to detect with certainty the phenomena of lexical borrowings which would illuminate the cultural and linguistic contacts which we already know existed through the archaeological record. In the absence of full access to the lexicon, grammar and syntax, we are unable to tell whether southern Gaul developed a specific form of Iberian or whether one single language was used as a lingua franca, or indeed as a koine, between multiple groups. The very nature of the texts, which are often limited to marks of ownership, does not allow us to decide whether the writers, beyond being able to use the north-eastern script to write their names, actually knew any Iberian. In fact the few elements of Iberian grammar that we do understand, namely suffixes marking belonging, provenance and perhaps number, are only very rarely attested in the Palaeohispanic inscriptions from southern Gaul. ${ }^{46}$ The hypothesis of a lingua franca used only at a written level could be envisaged, though it is difficult to see how this would work in practice. ${ }^{47}$

The idea of a spread of the lingua franca from south to north has been queried on chronological and palaeographic grounds, since the earliest Iberian inscriptions found in the north-east of the Iberian peninsula and in southern Gaul employ the 'dual system' of the script allowing the writers to distinguish voiced and voiceless stops using diacritics. This system is well attested in the Catalan and Languedocian regions in the fourth century BC and is earlier than its attestation elsewhere. ${ }^{48}$ This might indicate an earlier development of the north-eastern script in the north and a spread from north to south of the script and lingua franca. We can see that writers in Languedoc, in addition to the use of the dual system, developed several new signs, of which one, in the shape of downwards pointing arrows, only appears at Ensérune, ${ }^{49}$ indicating a certain amount of innovation and creativity in the use of script in the area. However, there is no clear evidence to suggest that Catalonia and Languedoc developed their own regional variety of Iberian and the vast majority of available texts are not long enough even to be sure that the dual system was employed in a systematic manner. ${ }^{50}$ So, neither the question of the origin of the script, nor the possible direction of spread of the proposed lingua franca, can be solved given the current state of documentation.

Javier de Hoz has suggested that the creation of the dual system in south-western Gaul should be seen as a response to linguistic contacts between Iberian and Indo-European populations,${ }^{51}$ and grew out of the need to adapt the Palaeohispanic script to names with sounds unfamiliar to Iberian speakers. Amongst the signs created for the dual system we should note the systematic use of certain signs to represent sounds specific to Gaulish or Latin, for example the use of the sign $<\dot{r}>$ in the transcription of Latin and Celtic names in south-western Gaul and the north-east of the Iberian peninsula. ${ }^{52}$ Given that the dual system is relatively well dated to between the fourth and second centuries BC, we might

\footnotetext{
${ }^{45}$ See Chapter 7.

${ }^{46}$ Moncunill 2016.

${ }^{47}$ Hoz 2011a: 462; Ruiz Darasse 2013.

${ }^{48}$ Ferrer 2005: 970

${ }^{49}$ On some coins from the Vasconian area in the mid-second century BCE, a similar sign is used with the value of an -e: sesars (Mon.44).

${ }^{50}$ Hoz 2011a: 214.

${ }^{51}$ Hoz 2011a: 215.

${ }^{52}$ Ruiz Darasse forthcoming.
} 
assume that the linguistic contacts between Celtic and Iberian groups might have been particularly intense and fruitful during this period. They did not, however, survive more intensive integration into the Roman world: after this period Latin and its script rapidly took over as the lingua franca.

It is not possible to recover much information about the origins and motives of the first Iberian speakers who set themselves up in south-western Gaul, though many modern commentators view the draw as economic and some have suggested seeing them as equivalent to metics in the Greek world. ${ }^{53}$ The Iberian groups, though presumably a minority in the area, seem to have had an impact locally far beyond the linguistic, the origin of which may lie in a certain prestige attached to their way of life, perhaps linked to their economic and productive prowess. The Iberians were clearly involved in the economic sphere in the area ${ }^{54}$ and they have been envisaged as middle men acting between both large and more modest Mediterranean trading partners. ${ }^{55}$ During the last five centuries BCE, Roussillon and Aude imported different material: in the fifth century BC Roussillon seems to be importing from nearby Catalonia, whereas in the Languedoc material was travelling from further afield,${ }^{56}$ sometimes from Andalusia, as attested by a small lead tablet found at Lattes (HER.01.03) and inscribed using the Meridional Palaeohispanic script mentioned above. These well-established trading lines persisted throughout the Iron Age. The products exchanged were not always standard everyday items but sometimes impressive pieces of metal work which may have been exchanged or given in the context of diplomatic relations or xenia. This may well be the case, for example, with the inscribed phiales found at Aubagnan (Landes), which may date to c. 200 BC and for which exact comparanda can be found in the treasure from Tivissa in Catalonia dated to the fourth to third centuries BC.

\section{Contacts in a Roman Mediterranean}

At about the time that direct linguistic evidence for Iberian is waning in the south-western zone, Celtic-speaking communities in the south-eastern zone, and especially in the lower-Rhône delta, are advancing onto the epigraphic stage with their use of Greek script to write Celtic, an epigraphy known as 'Gallo-Greek'. This has been traditionally attributed to the result of a process of 'Hellenization' and of contacts between 'elites' at Marseille. ${ }^{57}$ Recent research has instead suggested that the distribution of texts (MAP 1), the time-period, the lack of Greek linguistic features in the texts and the evidence of Italic languages within them may mean that we ought to see the phenomenon of Gallo-Greek as part of a more complex process of 'Mediterraneanization' with influences from a range of actors, including colonial Greeks, but also various Greek and other linguistic groups from the Italian peninsula and elsewhere. ${ }^{58}$ The epicentre of the phenomenon lies on the confluence of several key fluvial routes, with the Rhône running from north to south through the centre, with Marseille outside the epigraphic zone, suggesting that the focus on more complex origins may not be misplaced. The analysis of the

\footnotetext{
${ }^{53}$ Hoz 2011a: 119.

${ }^{54}$ Hoz 2011a: 468.

55 Bats 2011a: 134.

56 Gailledrat 1993: 77.

${ }^{57}$ For the adoption at Marseille, see Bats 2003: 372; Lambert 1992: 290-291, 1997: 36. There is no evidence to refute this claim, though, despite the impression to the contrary in the literature, the script used is not diagnostic: it is the form of the standardized Ionic alphabet used throughout the Greek-speaking world to write Koine Greek. Mullen (2013a: 110-112) argues that we cannot exclude possible multiple origins for the script, and notes that a multicultural maritime hub such as Martigues might suit the invention and graffiti found at the site suggest a period of experimentation with the notation of Gaulish names in Greek script.

${ }^{58}$ Mullen 2013a.
} 
precise forms of the script indicate that handwritten Greek may have been the model, which may also encourage us to envisage a trading context for the contact and motivation required for the initial borrowing. ${ }^{59}$ The time period in which Gallo-Greek is securely attested has been brought forward by Michel Bats to start as late as the last quarter of the second century BC, based on his view that several of the oldest 'Gallo-Greek' texts may be Greek. ${ }^{60}$ Rather than seeing Gallo-Greek as the result of Hellenization of indigenous groups, we might rather see the timing of this phenomenon as the result of changes within the indigenous societies and the intensifying Roman role in the region: Aquae Sextiae (Aix-en-Provence, Bouches-du-Rhône) was founded in $123 \mathrm{BC}$ and integration progressed until the formal incorporation of the area under the Imperial aegis of Augustus in 27 BC.

Although the origins of Gallo-Greek probably begin with graffiti on ceramic and may be associated with trading contexts and internal settlement requirements, the lapidary development can perhaps be associated with additional factors in the evolving cultural environment of the first century, including increasing numbers of 'non-indigenous' individuals in the hinterland, partly due to influxes from the Italian peninsula. These incomers bring not only the notion of an 'epigraphic habit', which does not appear to have been embraced by Phokaian Greeks, but also a motivation for local expression in this new world order. The distribution of the texts strengthens the argument: the most prolific sites for lapidary Gallo-Greek are Glanum, Nîmes and Cavaillon, all of which later become significant Roman settlements. In addition the non-Gaulish linguistic features in these texts can be related to the Italian peninsula. We find a praetor, ПРАIT $\omega \mathrm{P}$ (RIG I G-108), attested at Vitrolles (Bouches-du-Rhône) which perhaps indicates an investment, at least superficially, in Roman modes of organization. Similarly the non-Gaulish names can be linked to Italian origins and as yet none of the non-Gaulish names in the published Gallo-Greek inscriptions is definitely Greek or Iberian: ${ }^{61}$ P[?]OY|MAN[I/E?]|OC (Collias, RIG I G-183), KOPNHAIA (Glanum, RIG I G-65), CKOYPPA (Cavaillon, RIG I G-141), KOYA $\triangle$ POYNIA (RIG I G-106), KAEIOC (Velleron) ${ }^{62}$ and $\Gamma A I O C$ (Gaujac, RIG I G-198). The main recurring formula, the Celtic $\triangle \mathrm{E} \triangle \mathrm{E}$ BPATOY $\triangle \mathrm{EKANTEN,}$ probably meaning 'gave a tithe in gratitude', can be linked to influences from a Mediterranean koine, and communities from central-southern Italy provide all the elements and appropriate circumstances for contact-induced adoption. ${ }^{63}$

Inscriptions containing deity names are particularly important for indicating cultural continuity and early Italian influence. ${ }^{64}$ The $\triangle \mathrm{E} \Delta \mathrm{E}$ BPATOY $\triangle \mathrm{EKANTEN}$ dossier is well represented at Glanum

\footnotetext{
${ }^{59}$ Mullen 2013a: 101-106.

${ }^{60}$ Bats 2011b: 212-217.

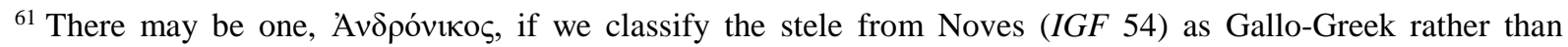
Greek. This example raises an important problematic point: the classification of Gallo-Greek inscriptions as opposed to Greek can be, in the absence of firm diagnostic linguistic features, relatively arbitrary, relying on the linguistic origins of the names themselves and the labelling of the find spot in material culture terms, see Mullen 2013a: 149-152, 153-157 for detailed discussion.

${ }^{62}$ Bats 2011b: 223.

${ }^{63}$ For a full discussion of this formula and the view that it derives from contact with the Mediterranean koine, see Mullen 2013a: 189-219. For the breakthrough segmentation of the scriptura continua, see Szemerényi 1974, whose analysis is, in keeping with the scholarship of the time, oriented towards Marseille.

${ }^{64}$ For the process of interpretatio, see Häussler 2004-2006: 146-153; Rives 2007. Interpretatio and syncretism are better attested in the West for Roman- and Celtic-named deities than Greek and Celtic, though there are

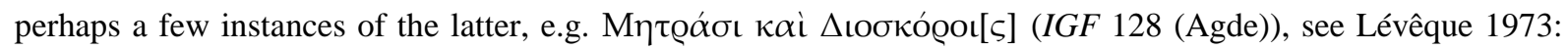
53-55.
} 
(Bouches-du-Rhône) with three out of fourteen examples occurring at this site. Possible evidence of cultural continuity can be revealed by investigating the inscription containing the only non-Celtic name in Glanum's Gallo-Greek record: KOPNHAIA (RIG I G-65, Fig. 3), the Latin name Cornelia. This inscription includes the $\triangle \mathrm{E} \triangle \mathrm{E}$ BPATOY $\triangle \mathrm{EKANTEN}$ formula and is dedicated to the POK $\Lambda$ OICIABO, thought to be the 'far-hearing goddesses'. This might be compared to the beautifully carved Latin inscription from Glanum to the Auribus (IAG 18, Fig. 4) of the first or second century $\mathrm{AD}$, complete with a carving of a pair of ears within a wreath. ${ }^{65}$ The name of the pia ministra who dedicates is Loreia, a rare name, whose attestations outside Gallia Narbonensis (where it is found at Glanum and Narbonne (CIL XII 4731)) are restricted to Italia and Alpes Poeninae. This might highlight continuity of practice, illustrated in the Gallo-Greek record by a woman possibly from Italy, or with connections to Italy, worshipping the Celtic far-hearing goddesses and continued, in Latin guise to the Auribus, by another woman, perhaps from Italy.

The corpus of Gallo-Greek inscriptions from south-eastern Gaul contains virtually nothing other than onomastic evidence and the $\triangle \mathrm{E} \triangle \mathrm{E}$ BPATOY $\triangle \mathrm{EKANTEN}$ formula. The Gallo-Greek inscription from Velleron (Vaucluse) is therefore unusual in that it provides a verb. This Gaulish stele is the only secure instance of a bilingual text involving Gaulish from southern Gaul. ${ }^{66}$ It takes a standard 'Celtic' form with triangular summit and probably dates to the first century BC (Fig. 5) ${ }^{67}$

1. KAEIOC

2. IN $\triangle \mathrm{OYTI \Lambda}$

2a. $\mathrm{O}$

3. САMO $\triangle \mathrm{A}$

4. TICANE

5. KTIA

6. OYA $\Lambda$ HTE

The format of the inscription appears most likely to be two masculine personal names, KAEIOC IN $\triangle$ OYTI $\Lambda$ O 'Gaius Indoutilos', followed by two feminine personal names, CAMO $\Lambda$ ATIC ANEKTIA 'Samolatis Anektia', and a plural Latin verb ualete 'farewell'. The onomastic evidence in the Gallo-Greek inscriptions consists of either a simple name or a name plus patronymic adjective. Do the first two names mark a break in this standard practice and reflect a duo nomina formation? In the second and first centuries, the standard system in Latin was the praenomen and nomen. The first name KAEIOC may be a rendition of the common Latin praenomen Gaius, written Caius in standard Latin orthography, due to the fossilization of the form when /g/ was represented by $\mathrm{C} .{ }^{68}$ This would imply a knowledge of conventional Latin orthography on the part of the author of the text. The second character, probably female, appears to have a 'traditionally' Gaulish name. The formation seems to be a personal name plus an adjectival patronymic in -ia. It could be argued that we are treating four

\footnotetext{
${ }^{65}$ Blétry 1998. A similar altar is dedicated to Bonae Deae at Arles (CIL XII 654), again with a pair of ears within a wreath, perhaps a different interpretatio of the same Celtic deities. An inscription to Bonae Deae was also found at Glanum nearby that to the Auribus in house VII.

${ }^{66}$ There may be another from Olbia, IGF 66, see Mullen 2013a: 171-173.

${ }^{67}$ The typology has been designated as essentially Celtic (Bessac, Gasco, Michelozzi, Lejeune 1986: 62) or as demonstrating Greek or Etruscan origins (e.g. Jacobsthal 1931: 212). Whatever its origins, the form seems to be distinctively 'local' in the context of southern Gaul in this period.

${ }^{68}$ In lapidary inscriptions Caius and its abbreviated variant are found almost exclusively, see Clackson and Horrocks 2007: 96 for spelling conventions.
} 
separate characters: KAEIOC, IN $\triangle O Y T I \Lambda O C, C A M O \Lambda A T I C$ and ANEKTIA. However, the order of the names, with a Latin praenomen in first position, and a possible patronymic in last position, indicates that we are dealing with two ${ }^{69} \mathrm{~A}$ bi-partite naming formula is common in Gallo-Greek lapidary inscriptions, and the exact formation of female name plus patronymic adjective can be securely attested four times in $R I G$ I (G-106, 107, 146, 211), which is not inconsiderable considering the relatively low number of well-understood Gallo-Greek lapidary inscriptions involving women.

The object, script, morphology and, except for the first name, onomastics, identify the inscription as Gaulish and as contemporary with the bulk of the Gallo-Greek inscriptions. The verb at the end cannot be Gaulish, Iberian or Greek, but is a transliteration of the Latin verb ualete into Gallo-Greek. This final address is an example of code-switching and might be a deliberate ploy on the part of the author to show the Gaulish pair's complicity with the Italian contact culture. uale appears repeatedly in multicultural centres such as Rome and Pompeii and Paolo Poccetti points out that 'an enormous quantity of Latin inscriptions from the late Republican period onwards attests this practice of imitating oral greeting, ${ }^{70}$ We might view the verb, in many cases, as a common, perhaps 'colloquial, ${ }^{71}$ element in Latin inscriptions and equivalents can also be found in the Italic languages ( $S T$ Lu 40, MV 6, Pg 11). ${ }^{72}$ The most plausible explanation of the code-switch seems to be that the Gaulish author has chosen to use a Latin verb, but has picked one familiar through contact with Italians, rather than a formula more standard for Latin funerary epitaphs (e.g. HSE, DM). Contacts with the Italian peninsula occurred at least as early as the third century and have a much more substantial role in the creation and development of Gallo-Greek than has traditionally been allowed. The Gallo-Greek evidence is now being discussed in terms of interaction with a Mediterranean koine rather than primarily and exclusively the Massaliote colonies.

We saw above that evidence for interaction between Phokaian colonists and indigenous groups was extremely rare in the pre-Roman epigraphy, but under the period of rising Roman influence some of the best evidence for linguistic and cultural interaction between Greek-named and Celtic-named individuals can be found. At the rock sanctuary known as La Tour de l'Acapte on the Presqu'île de Giens thousands of fragments of ceramic have been uncovered equating to hundreds of Greek inscriptions. ${ }^{73}$ These indicate that the sanctuary is dedicated to Aristaios and the dedicators have a mixture of both Greek and Celtic names. ${ }^{74}$ The naming practices and formulae at the site show striking instances of negotiation between the two languages within a Greek discourse, including hybrid names, which distinguish this site in the context of Gaulish-Greek relations in south-eastern Gaul, and

\footnotetext{
${ }^{69}$ Bats suggests that we could view the names as consisting of a male tria nomina, KAEIOC IN $\triangle O Y T I \Lambda O$ CAMO $\Lambda$ ATIC, followed by a single female idionym, ANEKTIA, in which case, the man represented on the stele 'pourrait être alors l'un de ces premiers indigènes ayant accédé à la citoyenneté romaine, mais ayant conservé dans son appellation son identité gauloise' (2011b: 225). This analysis is not impossible, though the ordering of the names and the comparanda (for which, see Mullen 2013a: 182-189) suggest that a duo nomina followed by an idionym plus patronymic is more plausible.

${ }^{70}$ Poccetti 2010: 106.

${ }^{71}$ See Poccetti 2010 for a discussion of the colloquial nature of this greeting.

${ }^{72}$ See Untermann 2000: 823.

${ }^{73}$ These are still not fully published, see IGF 68; Bats 2004: 16-17; Giffault and Coupry 1990; Mullen 2013a: 243-263 for discussions.

${ }^{74}$ There are also two Latin names, see Bats 2004: 10-12; Mullen 2013a: 243-262 with table 11 for details of the names.
} 
possibly in terms of evidence for Celtic-Greek interaction anywhere. The sanctuary is found at a distance of around 5 kilometres from the Phokaian colony Olbia (Var), and shows Celtic-named individuals apparently intimately involved in a Greek rural cultic context. Though evidence elsewhere suggests that the Greek language was largely restricted to colonies and trading contexts, this epigraphic cache reminds us of the heterogeneity of interactions and communities and the dangers of over-generalization.

To the west of the Hérault in Gaul no Greek name has been found transcribed in Iberian and no example of the adaptation of the Greek script for Iberian as there was in the fourth century BC in Contestania (Graeco-Iberian script). However several series of coin legends from Languedoc, dated to the second and first centuries BC, illustrate the interactions between the Greek and Iberian worlds. Some of these issues have two legends, one in the north-eastern script and the other in Greek script (e.g. biuŕbi/ $\Lambda$ ОГГО $\Sigma \mathrm{TA} \Lambda \mathrm{ET} \Omega \mathrm{N}$, Mon.02, leyenda 1). On two of them, we find on the reverse Celtic

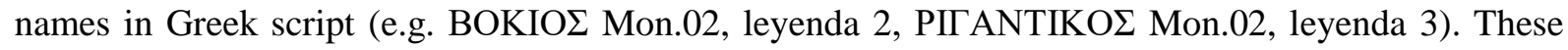
coins are the most 'hellenized' coins known in southern Gaul as they are imitations of the Massaliote bronzes with tripods. ${ }^{75}$ Their distribution is restricted to Languedoc and the Aude valley up to Toulouse. ${ }^{76}$ Other coins found on the coast of Languedoc contain Celtic names of men identified as 'kings' through the term $\beta \alpha \sigma i \lambda \varepsilon v$ c. These coins attest the complex relations between the various parts of the 'indigenous', Iberian and the Graeco-Roman worlds, since they also have an iconography which links them to the Iberian issues of Iltirta/Lérida (e.g. KAIANTO $\Lambda O Y$ IBL 2416) or of Kese/Tarragone (for the reverse, e.g. BITOYKOC IBL 2408 with a bounding lion) ${ }^{77}$ Furthermore the metrology and denominations of these issues (as, semis) can be directly linked to the Roman system. ${ }^{78}$ These coins demonstrate the complexity of the entanglements in southern Gaul in the late pre-Imperial period.

In the middle of the second century BC (between 175 and 150/130 BC), we can be sure of close contacts and trade between Iberian-, Latin- and Gaulish-speaking groups in Vieille-Toulouse (HauteGaronne), thanks to amphorae marked with north-eastern characters in red paint found in wells (Fig. 6). ${ }^{79}$ Several interpretations have been advanced for the sequences linking the names with the following: quantity, date, ${ }^{80}$ price,${ }^{81}$ lot number and, more recently, tolls.$^{82}$ This appears to be a unique epigraphic group and to represent a 'processus typiquement tolosate' ${ }^{83}$ Amongst the names we find Latin names (e.g. babirgi/PAPIRIUS or FABRICIUS; binugi/VINVCIUS; curti/CURTIUS; seste/SEXTIUS), Celtic (e.g. anbi) and Iberian (e.g. sakar) ${ }^{84}$ One of these marks, using the same technique and clearly

\footnotetext{
${ }^{75}$ Feugère, Py, 2011: 301. These authors propose a late third century BC to beginning of the second century BC date, whereas García Bellido 2001 and the Hesperia database offer a more recent date of the beginning of the first century BC.

${ }^{76}$ Feugère, Py, 2011: 304 (map).

${ }^{77}$ Feugère, Py, 2011: 297.

${ }^{78}$ Ibid. This makes sense when we consider that Iberian Kese became Roman Tarragone in 218 BC and the coins of Languedoc are dated to the middle of the second century BC.

${ }^{79}$ Vidal, Magnol 1983; Lejeune 1983b; Gorgues 2010: 309-325.

${ }^{80}$ Lejeune 1983b: 35.

${ }^{81}$ Lejeune 1983b: 36.

${ }^{82}$ Gorgues 2010: 317.

${ }^{83}$ Gorgues 2010: 311.

${ }^{84}$ Editio princeps: Vidal, Magnol 1983; Lejeune 1983b.
} 
belonging to the same ensemble, is written with the Latin alphabet and gives the Latin name Q. OFELI, followed by a sequence of Iberian metrological signs. This inscription confirms the knowledge of at least two writing systems by the same writer. The texts are on Graeco-Italic amphorae but are associated with cookware of Massaliote origin, leaving open the possibility that there also may have been Greek individuals on site. This group of texts would have remained an isolated case if new finds had not backed up the picture of multiculturalism. On the nearby site of the Quartier Saint-Roch other inscriptions dating to around 125-100 BC include Greek names also attested at Marseille in levels with inscriptions in north-eastern script. ${ }^{85}$ Even if these short inscriptions cannot allow us to reach firm conclusions about the precise nature of the interactions, we can nonetheless be certain that the northeastern script was being used at Vieille-Toulouse at a relatively late period for writing Iberian (cf. lakei $)^{86}$ and for transcribing local names, ${ }^{87}$ alongside Latin and Greek.

With the exception of a few isolated cases, such as that of Vieille-Toulouse, the Latin language and alphabet replaced the north-eastern script in southern Gaul from around the time of the creation of the Roman provincia. Palaeohispanic epigraphy disappears totally in the space of a few decades and, within Latin epigraphy in southern Gaul very few inscriptions mention Iberian-named individuals or those described as hailing from the Iberian peninsula. ${ }^{88}$ Occasionally traces of the survival of indigenous languages and identities can be recovered in isolated areas, for example the remote valleys of the Pyrenees where votive inscriptions inscribed in Latin script dating from the first century $\mathrm{BC}$ to the third century $\mathrm{AD}$ contain local personal and deity names. ${ }^{89}$ These are the last epigraphic witnesses in southern Gaul of groups whose origins can be clearly traced amongst the populations of the Iberian peninsula. Javier de Hoz describes a 'latinisation différenciée' in south-western Gaul between Iberianand Gaulish-speaking communities. The former barely have a voice through non-Palaeohispanic epigraphies. Conversely, the latter had already used the Iberian and Greek scripts for writing their names, elsewhere in Gaul had adopted the Greek, and later, the Roman script ('Gallo-Latin') more extensively, and large numbers of Celtic names can be found in Imperial Roman epigraphy throughout southern Gaul..$^{90}$

In fact there are really only two instances of lapidary Gallo-Latin (Gaulish written in Latin alphabet) from southern Gaul in RIG II.1, both from the Bouches-du-Rhône: VECTIT[... / BIRACI[... (L-1, Ventabren) and BOVDIL/ATIS $\cdot$ LEMISVNIA (L-2, Coudoux). ${ }^{91}$ The latter might be more securely

\footnotetext{
${ }^{85}$ Moret, Ruiz Darasse, Verrier 2015.

${ }^{86}$ Moret, Ruiz Darasse, Verrier 2015: 409-410.

${ }^{87}$ Moret, Ruiz Darasse, Verrier 2015: 411-413, unless it is a writing exercise.

${ }^{88}$ CIL XII, 735, Arles: D(is) M(anibus) / Metelliae Protidis / matri / Birbilitan(ae) Lucinae (which may link to Bilbilis in Hispania Tarraconensis); CIL XII, 828, Arles: D(is) M(anibus) / Iuliae Politic(a)e / L(ucius) Cornelius / Hiberus uxori / karissimae; CIL XIII, 874, Bordeaux: Val(eriae) Hi/berin(a)e / Quartil/la mater p(osuit) / et P(ublicio?) Lucio / marito / pientis(simo) p(osuit); CIL XII, 5686, 418a, Aoste, and CIL XIII, 10010, 1016a, La Graufesenque: Iberius.

${ }^{89}$ For a revised corpus of this material, see Gorrochategui 2013. For a catalogue of the altars, see Rodriguez and Sablayrolles 2008.

${ }^{90}$ For Gallia Narbonensis, see Untermann 1969. For Aquitania, see Gorrochategui 1984. For the Celtic names of Gaul more generally, see Delamarre 2007; Evans 1967; Schmidt 1957. For names and bilingualism in the graffiti from La Graufesenque, see Adams 2003: 687-724; Marichal 1988; Mullen 2013b.

${ }^{91}$ See the discussion in RIG II.1: 63-68 and Lejeune 1977. This leaves: one inscription from Orange (RIG II.2 L18), about which Lambert notes 'il ne s'agit pas d'une véritable inscription gallo-latine, mais de la citation, en contexte latin, d'un mot gaulois' (RIG II.2: 36); the Amélie-les-Bains tablets (L-97), which possibly contain
} 
assigned to Gaulish as it contains the Gaulish patronymic suffix -ia. However, the Ventabren stele does not provide any diagnostic features, and may well be Latin (containing Gaulish names). Michel Bats points out that Michel Lejeune ${ }^{92}$ is wrong to propose 'une évolution en trois volets (gallo-grec jusqu'à César, puis gallo-latin jusqu'à Claude et enfin latin) ${ }^{\prime} ;{ }^{93}$ Gallo-Latin is instead found alongside later phases of Gallo-Greek and early Latin. ${ }^{94}$ Indeed, we might wonder whether a Gallo-Latin phase can be posited for southern Gaul at all: ${ }^{95}$ the evidence for a Gallo-Latin epigraphic phase is largely restricted to inscriptions on local coins in Latin script, some of which are likely to have been envisaged as Latin. ${ }^{96}$ We might wonder why, in contradistinction to the situation in Tres Galliae, Gallo-Latin is so rare in southern Gaul. The lack of Gallo-Latin could be interpreted as resistance to Roman culture, but, considering the large numbers of Celtic names employed in the Latin inscriptions, another solution appears more cogent. Adoption of the Latin language and Roman methods of writing may have been more advanced than elsewhere in Gaul and hence Gallo-Latin was superfluous. ${ }^{97}$

Situated on the edge of the Palaeohispanic world, southern Gaul represents a colourful area in which a range of Mediterranean and local communities interacted over several centuries and traces have been uncovered which indicate clearly the important role that Iberian populations played beyond the confines of the Iberian peninsula. The complex epigraphy of this area is one key output of intense linguistic and cultural interactions and seems to have reached its apogee in the third to second centuries in the western zone and the second to first in the east, receding dramatically under the standardizing pressure of the Roman Empire with its successful lingua franca and epigraphy.

elements of Gaulish in Latin script, though caution must be exercised as this is a magical text known only through transcriptions; and perhaps one or two fragmentary graffiti whose linguistic affiliations are uncertain (see Bats 2011: 220 for a handful of possible examples).

${ }^{92}$ Lejeune 1983a.

${ }^{93}$ Bats 1988: 145.

${ }^{94}$ Bats refers to a rare inscription from Entremont in cursive Latin with Greek letters, and coin legends from 'Gaule interne' demonstrating confusions such as Greek rho for Latin R and the lunate sigma for Latin S (1988: 146). Moberg 1987 discusses bilingual coin legends.

${ }^{95}$ Langslow 200233 notes that script is often the first aspect to be affected in language shift, even before onomastics.

${ }^{96}$ Though some with terminations have Celtic - OS (RIG IV 32, 49, 70) and RIG IV 148 possibly shows the same inscription in 'Gallo-Latin' DVRNACOS / AVSCROCOS and 'Latin' DVRNACVS / AVSCROCVS.

${ }^{97}$ Lambert 1992: 294. 
Adams, J.N. 2003. Bilingualism and the Latin language. Cambridge.

Amadasi Guzzo, M.G. 1967. Le iscrizioni fenicie e puniche delle colonie in occidente. Rome.

Ampolo, C., Caruso, T. 1990-1991. "I Greci e gli altri nel Mediterraneo occidentale. Le iscrizioni greca ed etrusca di Pech-Maho: circolazione di beni, di uomini, di istituti." Opus 9-10: 29-58.

Bats, M. 1988. "La logique de l'écriture d'une société à l'autre en Gaule méridionale protohistorique." RAN 21: 121-148.

Bats, M. 2000. "Du grec au gallo-grec, les débuts de l'écriture dans le Midi gaulois." In Le temps des Gaulois en Provence, ed. J. Chausserie-Laprée, 74-78. Martigues.

Bats, M. 2003. "Les Gaulois et l'écriture aux $\mathrm{II}^{\mathrm{e}}-\mathrm{I}^{\mathrm{er}}$ s. av. J.-C.." In Les marges de l'Armorique à l'Age du Fer. Archéologie et histoire: culture matérielle et sources écrites, ed. B. Mandy and A. de Saulce, 369-380. Nantes.

Bats, M. 2004. "Grec et gallo-grec: les graffites sur céramique aux sources de l'écriture en Gaule méridionale ( $\mathrm{II}^{\mathrm{e}}-\mathrm{I}^{\mathrm{er}}$ s. av. J.-C.)." Gallia 61.1: 7-20.

Bats, M. 2011a. "Entre Ibères et Celtes : l'écriture à Ensérune dans le contexte de la Gaule du Sud $\left(\mathrm{V}^{\mathrm{e}}-\mathrm{II}^{\mathrm{e}}\right.$ s. av. J.-C.)." In A Greek man in the Iberian street, ed. E.R. Luján Martínez, J.L. García Alonso, 129-137. Innsbrucker Beiträge zur Sprachwissenschaft, 140. Innsbruck.

Bats, M. 2011b. "Emmêlements de langues et de systèmes graphiques en Gaule méridionale $\left(\mathrm{VI}^{\mathrm{e}}-\mathrm{I}^{\mathrm{er}}\right.$ siècle av. J.-C.)." In Contacts linguistiques dans l'Occident méditerranéen antique, ed. E.R. Luján Martínez, C. Ruiz Darasse, 197-226. Collection de la Casa de Velázquez, 126. Madrid.

Belfiore, V. 2015. "Graffiti etruschi dalla Gallia e il piombo di Pech Maho: alcune questioni paleografiche e contenutistiche." In Contacts et acculturations en Méditerranée occidentale: hommages à Michel Bats : actes du colloque de Hyères, 15-18 septembre 2011, ed. R. Roure, et alii, 537-543. Arles / Aix-en-Provence.

Bernard, L., Collin-Bouffier, S. and Tréziny, H. 2010. "Grecs et indigénes dans le territoire de Marseille.” In Grecs et indigènes de la Catalogne à la Mer Noire, ed. H. Tréziny, 131-145. Paris.

Bessac, J.-C., Gasco, Y., Michelozzi, A. and Lejeune, M. 1986. "Un nouveau monument funéraire gallo-grec à Beaucaire." Gallia 44.1: 55-64.

Blétry, S. 1998. "L'autel de Loreia Pia à Glanum et les 'divinités écoutantes."” RAN 31: 155-157.

Bouffier, S. and Garcia, D. 2017. Greek Marseille and Mediterranean Celtic region. New York.

Briquel, D., Gantès, L.-F., Gran-Aymerich, J. and Mellinand, P. 2006. "Marseille: nouvelles découvertes grecques et étrusques." Archéologia 432: 36-43.

Campmajo, P. 1992. Ces pierres qui nous parlent: les gravures rupestres de Cerdagne, PyrénéesOrientales, de la fin de l'âge du fer à l'époque contemporaine. Canet-en-Roussillon.

Clackson, J. and Horrocks, G. 2007. The Blackwell history of the Latin language. Malden, MA / Oxford.

Colonna, G. 1980. "Graffiti etruschi in Linguadoca." SE 48: 181-185.

Colonna, G. 2006. "A proposito della presenza etrusca nella Gallia Meridionale.” In Gli Etruschi da Genova ad Ampurias. Atti del XXIV convegno di studi etruschi ed italici, Marseille-Lattes, 26 settembre - 1 ottobre 2002. II, ed. S. Gori and M.C. Bettini, 657-678. Pisa / Rome. 
Correa, J.A. 1993. "Antropónimos galos y ligures en inscripciones ibéricas." In Studia Palaeohispanica et Indogermanica J. Untermann ab amicis hispanicis oblata, ed. I.-J. Adiego, J. Siles, J. Velaza, 101-116. Barcelona.

Delamarre, X. 2007. Les noms de personnes celtiques dans l'épigraphie classique. Paris.

Deroc, A. 1983. Les monnaies gauloises d'argent de la vallée du Rhône. Paris.

Dietler, M. 1997. "The Iron Age in Mediterranean France: colonial encounters, entanglements, and transformations." Journal of World Prehistory 11.3: 269-358.

Dietler, M. 1999. "Consumption, cultural frontiers, and identity: anthropological approaches to Greek colonial encounters." In Confini e frontiera nella Grecità d'Occidente: atti del trentasettesimo convegno di studi sulla Magna Grecia, Taranto, 3-6 ottobre 1997, ed. A. Stazio and S. Ceccoli, 475-501. Taranto.

Dietler, M. 2010. Archaeologies of colonialism. Consumption, entanglement, and violence in ancient Mediterranean France. Berkeley / Los Angeles.

Domínguez, A. J. 1999. "Hellenisation in Iberia?: the reception of Greek products and influences by the Iberians." In Ancient Greeks west and east, ed. G. R. Tsetskhladze, 301-329. Leiden.

Evans, D.E. 1967. Gaulish personal names. A study of some Continental Celtic formations. Oxford.

Ferrer i Jané, J. 2005. "Novetats sobre el sistema dual de diferenciació gràfica de les oclusives sordes i sonores.” Palaeohispánica 5: 957-982.

Ferrer i Jané, J. 2015. "Le nouveau corpus d'inscriptions ibériques rupestres de la Cerdagne (2): deuxième parution." Les cahiers de l'Âne Rouge 3: 7-22.

Feugère, M. and Py, M. 2011. Dictionnaire des monnaies découvertes en Gaule méditerranéenne (530-27 avant notre ère). Montagnac-Paris.

Gailledrat, É. 1993. "Les céramiques peintes ibériques au $\mathrm{V}^{\mathrm{e}}$ siècle avant J.-C. en Languedoc occidental et en Roussillon." DAM 16.1: 64-79.

Gailledrat, É. 1997. Les Ibères de l'Èbre à l'Hérault : VIe-IVe s. avant J.-C. Lattes.

Gailledrat, É. 2014. Espaces coloniaux et indigènes sur les rivages d'Extrême-Occident méditerranéen: Xe-IIIe s. avant notre ère. Montpellier.

Garcia, D. 2014. La Celtique méditerranéenne. Habitats et sociétés en Languedoc et en Provence $V I I^{e}-I I^{e}$ siècles av. J.-C. Second edition. Paris.

Giffault, M. and Coupry, J. 1990. "Giens.” In Voyage en Massalie. 100 ans d'archéologie en Gaule du sud, ed. P. Arcelin et al., 215-219. Marseille.

Gorgues, A. 2010. Économie et société dans le Nord-Est du domaine ibérique (III $-I^{e r}$ S. av. J.-C.). Anejos de Archivo español de Arqueología. Madrid.

Gorgues, A. 2016. "Trade in a liminal zone. Commercial encounter and transformation in the Iron Age North West Mediterranean.” In Cultural Encounters in Later Prehistoric Europe, ed. I. Armit, P. Hrvoje, M. Cresnar, P. Mason and L. Büster, 167-210. Budapest.

Gorrochategui, J. 1984. Estudio sobre la onomástica indígena de Aquitania. Bilbao.

Gorrochategui, J. 2013. "Révisions épigraphiques du corpus des dédicaces votives de la province d'Aquitania." In Théonymie celtique, culte, interpretatio. X. Workshop F.E.R.C.A.N., Paris 24.26. Mai 2010, ed. A. Hofeneder, P. De Bernardo Stempel, 25-44. Wien.

Gran-Aymerich, J. 2006. "Les Étrusques et l'extrême occident (VII $-\mathrm{V}^{\mathrm{e}}$ siècle av. J. C.): regards sur l'isthme gaulois et la péninsule ibérique." In Gli Etruschi e il Mediterraneo: commerci e politica: 
atti del XIII convegno internazionale di studi sulla storia e l'archeologia dell'Etruria, ed. G.M. Della Fina, 253-283. Rome.

Häussler, R. 2002. "Writing Latin - from resistance to assimilation: language, culture and society in N. Italy and S. Gaul." In Becoming Roman, writing Latin? Literacy and epigraphy in the Roman West, ed. A.E. Cooley, 61-76. Portsmouth, RI.

Häussler, R. 2004-2006. "Local religions in a global world.” ARP 10: 143-176.

Häussler, R. 2008. "At the margin of Italy. Celts and Ligurians in North-West Italy." in Ancient Italy. Regions without boundaries, ed. G. Bradley, E. Isayev and C. Riva, 45-78. Exeter.

Horden, P. and Purcell, N. 2000. The corrupting sea. A study of Mediterranean history. Oxford.

Hoz, J. de. 2005. "Ptolemy and the linguistic history of the Narbonensis." In New approaches to Celtic place-names in Ptolemy's Geography, ed. J. de Hoz, E.R. Luján Martínez, P. Sims-Williams, 173-188. Madrid.

Hoz, J. de. 2008. "A Celtic personal name on an Etruscan inscription from Ensérune, previously Considered Iberian (MLH b.1.2b)." In Celtic and other Languages in Ancient Europe. ed. J.L. García Alonso, 17-27. Aquilafuente, 127. Salamanca.

Hoz, J. de. 2010. Historia lingüística de la Península Ibérica en la Antigüedad. I, Preliminares y mundo meridional prerromano. Madrid.

Hoz, J. de. 2011a. Historia lingüística de la Península Ibérica en la Antigüedad II. El mundo ibérico prerromano y la indoeuropeización. Madrid.

Hoz, J. de. 2011b. "Las funciones de la lengua ibérica como lengua vehicular." In Contacts linguistiques dans l'Occident méditerranéen antique, ed. E.R. Luján Martínez, C. Ruiz Darasse, 27-64. Collection de la Casa de Velázquez, 126. Madrid.

Jacobsthal, P. 1931. "Les stèles funéraires celtiques de Glanum." Cahiers d'Histoire et d'Archéologie 2: 209-221.

Kleiner, F. S. 1973. "Gallia Graeca, Gallia Romana and the introduction of classical sculpture in Gaul." AJA 77.4: 379-390.

Lambert, P.-Y. 1992. "Diffusion de l'écriture gallo-grecque en milieu indigène." In Marseille grecque et la Gaule, ed. M. Bats, 298-294. Aix-en-Provence.

Lambert, P.-Y. 1997. "L'épigraphie gallo-grecque." In Actes du Xe congrès international d'épigraphie grecque et latine, Nîmes 4-9 octobre 1992, ed. M. Christol and O. Masson, 35-50. Paris.

Langslow, D. R. 2002. "Approaching bilingualism in corpus languages." In Bilingualism in ancient society. Language contact and the written text, ed. J. N. Adams, M. Janse and S. Swain, 23-51. Oxford.

Lejeune, M. 1977. "Épigraphie gauloise à Coudoux (B. du Rh.)." RAN 10: 59-75.

Lejeune, M. 1983a. "Rencontres de l'alphabet grec avec les langues barbares au cours du Ir millénaire av. J.C.." In Modes de contacts et processus de transformation dans les sociétés anciennes, 731753. Rome.

Lejeune, M. 1983b. "Vieille-Toulouse et la métrologie ibérique." RAN 16: 28-37.

Lejeune, M. 1993. "D’Alcoy à Espanca : réflexions sur les écritures paléo-hispaniques." In Michel Lejeune : notice biographique et bibliographique, 53-86. Leuven.

Lejeune, M., Pouilloux, J., Solier, Y. 1988. "Étrusque et ionien archaïques sur un plomb de Pech Maho (Aude)." RAN 21: 19-59. 
Lévêque, P. 1973. "Colonisation grecque et syncrétisme.” In Les syncrétismes dans les religions grecques et romaines, 43-66. Paris.

Marichal, R. 1988. Les graffites de la Graufesenque. Paris.

Marques de Faria, A. 1999. "Novas notas de onomástica hispânica pré-romana." Revista portuguesa de arqueologia 2.1: 153-161.

Moberg, C.-A. 1987. "Quand l'archéologue rencontre les rencontres d'alphabet... (Quelques réflexions sur des monnaies épigraphes celtiques)." In Mélanges offerts au Docteur J.-B. Colbert de Beaulieu, ed. C. Bémont, 639-647. Paris.

Morel, J.-P. 2006. "Phocaean colonisation." in Greek colonisation: an account of Greek colonies and other settlements overseas. Vol 1, ed. G. R. Tsetskhladze, 359-428. Leiden.

Morel, J.-P. 2006 [2009]. "De Marseille à Velia: problèmes phocéens.” CRAI: 1723-1782.

Moret, P., Ruiz Darasse, C., Verrier, G. 2015. "Ibère, Grec et Latin à Toulouse (Haute-Garonne) à la fin du II ${ }^{\mathrm{e}}$ s. av. J.-C. Nouvelles inscriptions sur céramique du site de la ZAC Niel." Gallia 72.2: 403-416.

Mullen, A. 2013a. Southern Gaul and the Mediterranean: multilingualism and multiple identities in the Iron Age and Roman periods. Cambridge.

Mullen, A. 2013b. "The language of the potteries: communication in the production and trade of Gallo-Roman terra sigillata." In Seeing Red: new economic and social perspectives on terra sigillata, ed. M. Fulford, E. Durham, 97-110. London.

Moncunill, N. 2016. “Novecientos antropónimos ibéricos.” Palaeohispanica 16: 87-101.

Poccetti, P. 2010. "Greeting and farewell expressions as evidence for colloquial language: between literary and epigraphical texts." In Colloquial and literary Latin, ed. E. Dickey and A. Chahoud. 100-126. Cambridge.

Ponsich, P. 1996. "Le masque punique de Collioure." Études roussillonnaises 14: 5-6.

Py, M. 1993. Les Gaulois du Midi: de la fin de l'âge de bronze à la conquête romaine. Paris.

Py, M. 1995. "Les Étrusques, les Grecs et la fondation de Lattes." In Sur les pas des Grecs en Occident, hommage à André Nickels, ed. P. Arcelin, M. Bats, D. Garcia, G. Marchand and M. Schwaller, 261-276. Paris.

Py, M. 2009. Lattara: Lattes, Hérault: comptoir gaulois méditerranéen entre étrusques, grecs et romains. Paris.

Rives, J. B. 2007. Religion in the Roman Empire. Oxford.

Rodriguez, L., Sablayrolles, R. 2008. Les autels votifs du Musée Saint-Raymond, musée des Antiques de Toulouse: catalogue raisonné. Toulouse.

Ruiz Darasse, C. 2010. "Les Ibères en Languedoc: l'onomastique celtique d'Ensérune en écriture paléohispanique." Palaeohispánica 10: 335-354.

Ruiz Darasse, C. 2013. "Ibère: langue véhiculaire ou écriture de contact?" In L'âge $d u$ Fer en Aquitaine et sur ses marges. Mobilité des hommes diffusion des idées, circulation des biens dans l'espace européen de l'âge du Fer, Actes du $35^{e}$ colloque de l'AFEAF, ed. A. Colin, F. Verdin. 397-406. Aquitania suppl. 30. Bordeaux.

Ruiz Darasse, C. forthcoming “'By any other name': Celtic names in palaeohispanic script. The case of Western Languedoc.” In Kelten, Römer, Griechen. Sprach- und Kulturkontakte im Römischen Reich und seinem Umfeld, G. Kloss, G. Broderick (ed.). Heidelberg.

Schmidt, K.H. 1957. Die Komposition in gallischen Personennamen. Tübingen. 
Simkin, O. 2012. "Language contact in the Iberian peninsula: direct and indirect evidence." In

Multilingualism in the Graeco-Roman Worlds, ed. A. Mullen and P. James, 77-105. Cambridge.

Szemerényi, O. 1974. "A Gaulish dedicatory formula.” KZ 88: 246-286.

Untermann, J. 1969. "Lengua gala y lengua ibérica en la Galia Narbonensis." Archivo de Prehistoria Levantin 12: 99-161.

Untermann, J. 2000. Wörterbuch des Oskisch-Umbrischen. Heidelberg.

Untermann, J. 2006. "Ligurisches.” In Studi linguistici in onore di Roberto Gusmani, ed. R. Bombi, G. Cifoletti, F. Fusco, 1759-1769. Alessandria.

Vallejo Ruiz, J.M. 2016. Onomástica paleohispánica. I. Antroponimia y teonimia. Bilbao.

Vidal, M., Magnol, J.-P. 1983. "Les inscriptions peintes en caractères ibériques de Vieille-Toulouse." RAN 16: 11-28.

Woolf, G. D. 1998. Becoming Roman. The origins of provincial civilization in Gaul. Cambridge.

\section{Abbreviations}

CIL: Mommsen, T. (ed.) 1862-. Corpus inscriptionum latinarum. Berlin.

$I A G$ : Rolland, H. 1944. "Inscriptions antiques de Glanum. Saint-Rémy-de-Provence. Révision et complément du Corpus inscriptionum latinarum." Gallia 2: 167-223.

IGF: Decourt, J.-C. 2004. Inscriptions grecques de la France. Lyon.

MLH: Untermann, J. 1980. Monumenta linguarum hispanicarum. II Die Inschriften in iberischer Schrift aus Südfrankreich. Wiesbaden.

RIG: Colbert de Beaulieu, J.-B., Duval, P.-M., Fischer, B., Lejeune, M., Lambert, P.-Y. and Pinault, G. 1985-. Recueil des inscriptions gauloises I, II.1, II.2, III. Paris.

ST: Rix, H. 2002. Sabellische Texte. Heidelberg.

\section{Map}

1 Map of southern Gaul showing places mentioned in the text (grey), sites with Palaeohispanic (yellow) and Gallo-Greek (green) inscriptions and Phokaian settlements (red).

\section{Figures}

1 Graffito from Ensérune containing a Celtic name in Etruscan script (Hoz 2008) (Photo: Coline Ruiz Darasse, by kind permission of the Musée archéologique d'Ensérune)

2 Graffito from Ensérune containing an Iberian name in Iberian script (HER.02.024) (Photo: Coline Ruiz Darasse, by kind permission of the Musée archéologique d'Ensérune)

3 Inscription from Glanum in Gaulish in Greek script, dedicated by Kornelia (RIG I G-65) (Photo: Alex Mullen, by kind permission of Glanum, Centre des monuments nationaux, Hôtel de Sade, SaintRémy-de-Provence)

4 Inscription from Glanum in Latin, dedicated by Loreia (IAG 18) (Photo: Alex Mullen, by kind permission of Glanum, Centre des monuments nationaux, Hôtel de Sade, Saint-Rémy-de-Provence) 5 Inscription from Velleron in Gaulish in Greek script, containing a code-switch into Latin (Bats 2011 fig. 33 (Photo: Michel Bats, by kind permission of Michel Bats)

6 Painted north-eastern Iberian characters from Vieille-Toulouse (Haute-Garonne) (Photo: JeanFrançois Peiré, by kind permission of Musée Saint-Raymond, Musée des Antiques de Toulouse) 